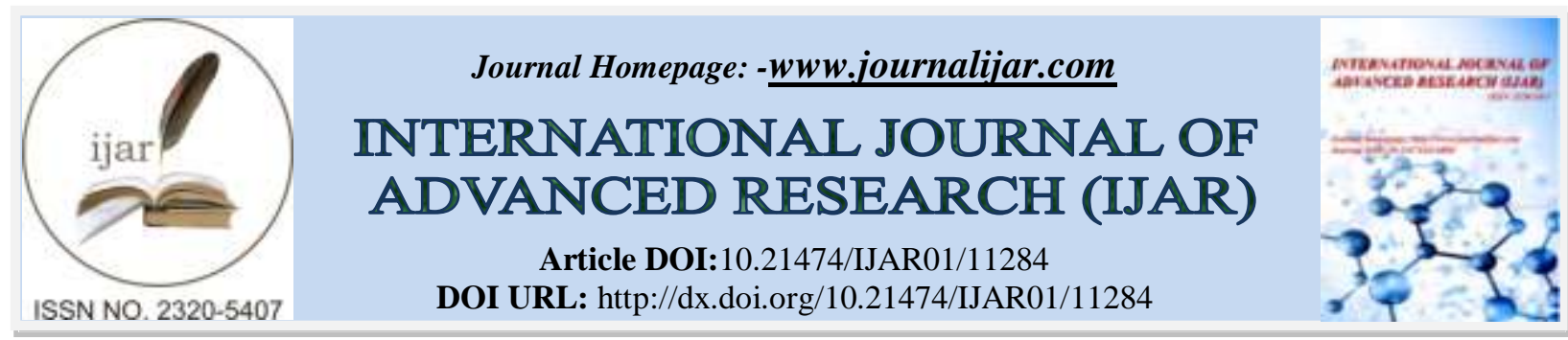

RESEARCH ARTICLE

\title{
SCREENING AND CHARACTERIZATION OF HEXAVALENT CHROMIUM DEGRADING BACTERIA FROM INDUSTRIAL SAMPLES
}

Gunti Vijay Kumar and Pandu Brahmaji Rao

Dept. of Environmental Science, Acharya Nagarjuna University, Guntur, Andhra Pradesh.

\section{Manuscript Info \\ Manuscript History \\ Received: 05 May 2020 \\ Final Accepted: 10 June 2020 \\ Published: July 2020 \\ Keywords:- \\ Bacillus Subtilis, Chromium (VI), \\ Degradation, Industrial Effluent, \\ Polymerase Chain Reaction (PCR)}

\begin{abstract}
Industrial wastes are capable of polluting the soil and groundwater, are taken into account as a possible environmental polluting agent throughout the earth. Chromium $(\mathrm{Cr})$, a virulent serious metal, could be a major constituent of industrial waste, and its accumulation in soil and water causes serious environmental problems with increasing public concern in India mainly in Telangana. This study deals with isolation and identification of $\mathrm{Cr}$ resistance microorganisms isolated from industrial effluents collected from Uppal region, Hyderabad. $\mathrm{Cr}$ resistance microorganism was isolated and the identification of the isolates was done by $16 \mathrm{~s}$ rRNA sequencing followed by BLAST results confirming the novel Bacillus subtilis strain. Moreover, the presence of Chromium reductase enzyme within the isolated microorganism was confirmed by PCR techniques. Bioremediation by microorganisms might offer an alternate or aid standard strategies of $\mathrm{Cr}$ metal removal capacity. The novel is known as $\mathrm{Cr}$ resistance microorganism would be helpful for the detoxification of heavy metal contaminated industry effluent and metal recovery in the mining method.
\end{abstract}

Copy Right, IJAR, 2020,. All rights reserved.

\section{Introduction:-}

Chromium pollution within the environment is because of the release of contaminants from industries [1]. The chromium and its compounds have many-sided industrial uses like production of refractory steel, electroplating, improvement agents, chemical process manufacture, lubricator, and conjointly within the production of acid. They are extensively used in animal skin trade particularly in Telangana, India [2]. These activities have led to the wide increase in contamination of chromium within nature and have influenced its bioavailability and bio quality [3]. Chromium is one among the category in hazardous waste [4] which may exist in several oxidization states. Though it will exist in 9 valence states, from -2 to +6 [5] only chromium (III) and also hexavalent chromium (VI) are important, since these are the most stable oxidization states within the natural conditions. Trivalent and hexavalent chromium has different physicochemical properties in biological systems. Metallic element dissent for the most part in Physico-chemical properties also as biological reactivity. The chromium (VI) species is very soluble and mobile within the environment, whereas chromium (III) species is far less soluble and relatively immobile [6]. This is often one among the explanation for recognizing, chromium (VI) as extremely toxic, carcinogenic for mammals and humans whereas chromium (III) is taken into account as a necessary element for aldohexose, lipoid, and amino-acid metabolism also as a dietary supplement [7]. Chromium (VI) is found to be one among the important common hazardous waste; therefore it should be treated before disposal. Usually, it's subjected to biological, chemical, and physical treatments. Bioremediation treatment by soil microorganism is considered the foremost appropriate 
technique since microorganism populations will show resistance to the maximum amount of chromium (VI). Chromium treatment through microorganisms is accepted because of the best and economically reasonable technology at this time to clean-up chromium contamination [8]. Staphylococcus aureus, Bacillus species, and a few species of enterica found to indicate resistance towards chromium. It was noted that some Chromium resistant microorganisms possessed the property of reduction with the assistance of reductase enzymes. The reductases found in chromium resistant microorganisms are capable to change state the reduction of hexavalent chromium (VI) to trivalent chromium (III) [9]. This property could also be because of the presence of chromate reductase [10]. So this study was performed to isolate and establish chromium reducing microorganisms from industrial effluent.

\section{Materials and Methods:-}

\section{Sample collection:}

The area for collection of samples within the study for this work was known to support the requirement, diversity, and extent of pollutants made by varied industries, situated in Hyderabad. The positioning was elect for the collecting samples- Soil from industrial effluents. Soil samples from industrial effluents were collected from JasperPvt Ltd. Uppal, Hyderabad town. A complete of ten were collected severally from completely different spots separated by $5-10 \mathrm{~m}$ distant from one another to hide a high vary of soil metal concentration. Soils and sediment cores were sampled from these sites. The soil samples from the primary selected contaminated place (industrial effluents) were collected from outside the plant in sterilized instrumentality or test tubes. These tubes were sealed and brought in autoclaved baggage to stop contamination from external sources and analyzed at the Sri Yuva biotech Pvt. Ltd, Hyderabad. The samples were maintained at or below $4^{\circ} \mathrm{C}$. Soil samples from the second contaminated site (metal dumping site) were collected in sterilized baggage and maintained at or below $4^{\circ} \mathrm{C}$.

\section{Isolation and enumeration of microorganisms:}

The microbes were isolated from effluent (semi-solid) by pour plating technique. $1 \mathrm{gm}$ of effluent was mixed with $9 \mathrm{ml}$ of sterile physiological saline $(0.85 \%)$ and serially diluted. From the various dilutions, $1 \mathrm{ml}$ of sample was pour plated with brain heart infusion agar and incubated for $24 \mathrm{~h}$ at $30^{\circ} \mathrm{C}$ to spot the number of colonies forming unit per gram of effluent.

\section{Pure culture of isolates:}

Out of assorted colonies obtained from serial dilution by pour plate technique, distinctive colonies were selected by the colony morphology. The chosen colonies were singly polite by streak plate technique in culture medium plate. The colony form, elevation, opacity, pigmentation, and texture of every isolate were ascertained.

\section{Chromium tolerance studies:}

The chromium tolerant microorganisms were identified by growing microorganism colonies on Mueller Hinton Agar medium modification with completely different concentrations of 20, 40, 60, 80, and $100 \mathrm{mg} / \mathrm{l}$ chromium against control (without chromium).

\section{Isolation of DNA from microorganism:}

DNA was isolated from microorganisms by Phenol-Chloroform technique. Using $0.5 \mathrm{ml}$ of $100 \mathrm{mMTris}-\mathrm{HCl}$ at $\mathrm{pH}$ eight.0, $0.1 \mathrm{ml}$ of $10 \mathrm{mM}$ EDTA at $\mathrm{pH}$ eight.0, $1.4 \mathrm{ml}$ of $1.4 \mathrm{M} \mathrm{NaCl}, 0.5 \mathrm{ml}$ of I Chronicles SDS, and $0.01 \mathrm{ml}$ of 0.2 $\%$ mercaptoethanol.

\section{Molecular identification of Chromium resistance organism:}

For the molecular identification of chromium resistance microorganisms, the 16S rRNA gene of the microorganism was amplified by PCR and sequenced. Universal forward primer 27F - 5'-AGAGTTTGATCCTGGCTCAG-3' and reverse primer 1492R - 5'-GGTTACCTTGTTACGACT-3' for amplification of 16S rRNA factor from isolated DNA. It had been analyzed for amplification exploitation $1.2 \%$ agarose gel followed by electrophoresis by using $1 \mathrm{X}$ TAE buffer and photographed the GELDOC gel documentation system.

\section{Phylogenetic analysis:}

The amplified 16S rRNA gene was purified and sequenced by using Sanger sequencing using constant primer used for PCR amplification. 16S rRNA factor sequences were exported into "Basic Local Alignment Search Tool" (BLAST) obtainable from the web site of the National Centre for Biotechnology Data (NCBI) to spot matches with existing characterized reference sequences. The output of BLAST searches was sorted supported most identity with alternative genus or species names in GenBank records. The DNA sequence was subjected to DNA editing and 
Noise editing employing a Bioinformatics package Bio Edit version seven.5. The phylogenetic trees were created by the 16S rRNA sequence of the chromium resistance organisms with reference sequence in GenBank exploitation MEGA package version seven.0 [11]. The edited DNA sequence was submitted to the GenBank NCBI and accession numbers were obtained.

\section{Results and Discussion:-}

\section{Isolation And Enumeration Of Microorganisms:}

The microorganisms were isolated from industrial effluent and were studied for colony morphology characteristics (Table 1). Colonies forming units per cubic centimeter were calculated as $1.42 \times 10^{4} \mathrm{CFU} / \mathrm{ml}$ from $10^{-1}$ dilution and were used to enumerate the microbial diversity within the collected industrial effluent. Similarly, shukla et al. (2007) declared that the microorganism colony count was $1.5 \times 10^{3}$ once it was isolated from the workplace. the economic effluent primarily consisted of metal and supermolecule [12], that makes it a perfect medium for several microorganism species to grow, to offer a significantly high CFU/ml of $1.42 \times 10^{4}$ for $10^{-1}$ dilution within this study. Nine distinctive colonies were isolated by streaking on to a separate agar plate. Similarly, the microorganism was known from industrial effluents and their tolerance limit was over $40 \mathrm{mg} / \mathrm{l}$ concentration of the metal (VI).

Table 1:- Colony characterization and microscopic examination of isolated microorganism.

\begin{tabular}{|l|l|l|l|l|l|l|}
\hline $\begin{array}{l}\text { Sr. } \\
\text { No } \\
-\end{array}$ & $\begin{array}{l}\text { Sample } \\
\text { collection } \\
\text { sites }\end{array}$ & Isolate No. & Colony color & Pigmentation & $\begin{array}{l}\text { Colony size } \\
\text { and texture }\end{array}$ & Gram's staining \\
\hline 1 & $\begin{array}{l}\text { Industrial } \\
\text { effluent }\end{array}$ & HI1 & Yellow & Yellow & smooth & Gram + bacilli \\
\cline { 3 - 7 } & HI2 & White & White & rough & $\begin{array}{l}\text { Gram } \\
+ \text { cocci }\end{array}$ \\
\cline { 3 - 7 } & HI3 & Dull White & White & smooth & $\begin{array}{l}\text { Gram } \\
\text { +cocci }\end{array}$ \\
\cline { 3 - 7 } & HI4 & Yellow & White & Smooth & $\begin{array}{l}\text { Gram } \\
\text { +bacilli }\end{array}$ \\
\cline { 3 - 7 } & HI5 & White & white & smooth & Gram - bacilli \\
\cline { 3 - 7 } & HI6 & White & Yellow & rough & $\begin{array}{l}\text { Gram } \\
\text { +bacilli }\end{array}$ \\
\cline { 3 - 6 } & HI7 & White & white & smooth & Gram + cocci \\
\hline
\end{tabular}

\section{Chromium metal tolerance:}

Chromium tolerance of isolated microorganisms was assessed by grown on Mueller Hinton medium containing different concentrations of metal. Eleven selected microorganisms reacted differently in several in a numerous manner to different concentrations of metal as illustrated in Table 2 and Fig. 1.

Table 2:- Biochemical characterization of the microorganism isolates.

\begin{tabular}{|c|c|c|c|c|c|c|c|c|c|c|c|c|}
\hline \multirow{2}{*}{$\begin{array}{l}\text { Sr. } \\
\text { No } \\
.\end{array}$} & $\overline{8}$ & \multicolumn{10}{|c|}{ Name of Biochemical Tests } & \multirow{2}{*}{$\begin{array}{l}\text { Bacterial species } \\
\text { Identified }\end{array}$} \\
\hline & & $8 \equiv$ & $\sqrt{3}$ & $\nabla$ & 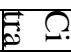 & & $\vec{E}$ Z & $\approx \Omega$ & ก T & $\cong 3$ & $\circ \cong 5$ & \\
\hline 1 & $\begin{array}{l}\text { HI2 } \\
\text { HI3 } \\
\text { HW6 }\end{array}$ & - & - & - & - & - & + & + & + & + & + & $\begin{array}{l}\text { Streptococcus } \\
\text { pyogenes }\end{array}$ \\
\hline 2 & HW4 HI7 & - & + & + & - & - & - & $\mathrm{A} / \mathrm{G}$ & + & + & + & Staphylococcus spp \\
\hline 3 & HI1 HI4 & - & - & + & + & - & - & + & + & - & - & Bacillus Subtilis \\
\hline 4 & HW3HW5 & - & - & + & + & - & - & + & + & + & Variable & Bacillus cereus \\
\hline 5 & HI5 & - & - & - & + & - & + & - & - & - & - & Pseudomonas spp. \\
\hline 6 & $\begin{array}{l}\text { HW2 } \\
\text { HW1 }\end{array}$ & - & + & - & - & - & $\mathrm{D}$ & $\mathrm{A} / \mathrm{G}$ & $\mathrm{A} / \mathrm{G}$ & $\mathrm{A} / \mathrm{G}$ & $\mathrm{A} / \mathrm{G}$ & Micrococcus spp. \\
\hline
\end{tabular}




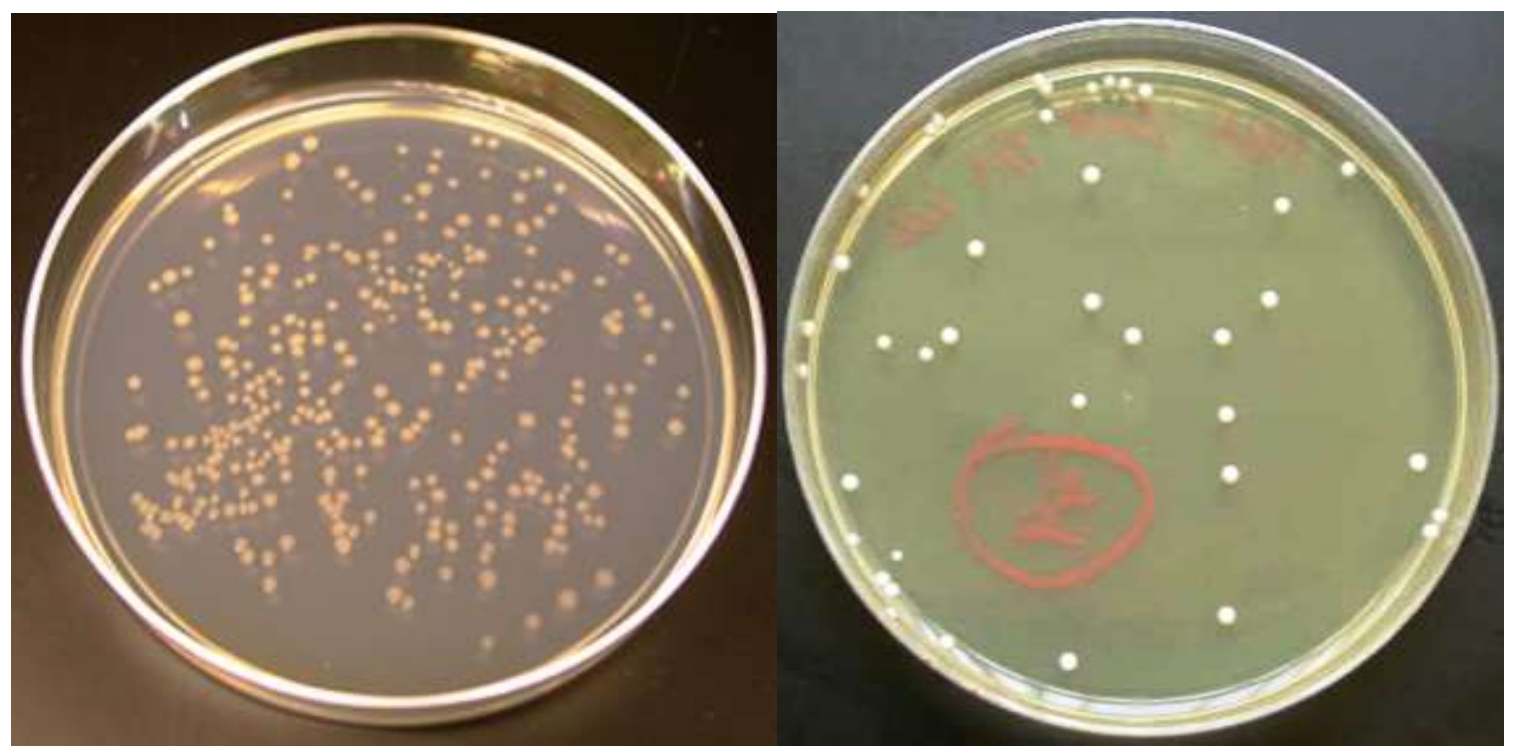

Fig 1:- Growth of colonies up to speed and 80mM concentration of hexavalent metal.

Out of the six microorganism strains, 2 microorganism strains exhibited metal tolerance to most of the metal concentrations. Strain HI1 had a positive growth up to $80 \mathrm{mg} / 1$ metal concentration and Strain HI4 had a positive growth up to $100 \mathrm{mg} / \mathrm{l}$ metal concentration (Table 3). Microorganism populations have been noted to point out resistance to the maximum amount as $500 \mathrm{mg} / 1$ chromium (VI) [13-15] that supports the positive growth of strain 1.5 up to $80 \mathrm{mg} / 1$ concentration and strain 2.4, a positive growth up to $100 \mathrm{mg} / \mathrm{l}$. Similarly, Wani et al. (2015) reportable that microorganism strains were resistant to chromium (VI). Among the microorganism strains, enterobacteria sp. showed the highest tolerance to metal (VI) in the agar plate dilution technique. additionally, see Pradhan et al. (2017), varied biological techniques won't to reduced toxicant substance from surroundings like microorganism and fungi, etc., the living organisms rework and take away chromium (VI) from water throughout the cellular metabolisms, living thing activities, physical and chemical adsorptions on the cell surface, and chemical process. The microorganism Cellulosimicrobium sp. (KX710177) isolated from workplace effluent, survived in the additional concentration of the metal (VI). Also, Shewanella lochia microorganism reduced the metal from the wastewater by the additional cellular method [16-19].

Table 3:- The average of $\mathrm{Cfu} / \mathrm{ml}$ for Bacillus subtilis inoculated in agar medium at totally different concentration of serious metal when forty-eight hrs.

\begin{tabular}{|c|c|c|c|c|c|c|}
\hline \multicolumn{7}{|l|}{ Bacillussubtilis } \\
\hline $\begin{array}{l}\text { Name of } \\
\text { heavy metal }\end{array}$ & $\begin{array}{lr}\begin{array}{lr}\text { Conc. } \\
\text { heavy } \\
(\mathrm{mM})\end{array} & \text { Of } \\
\end{array}$ & $\begin{array}{l}1^{\text {st }} \\
\text { experiment }\end{array}$ & $\begin{array}{l}2^{\text {nd }} \\
\text { experiment }\end{array}$ & $\begin{array}{l}\text { 3rd } \\
\text { experiment }\end{array}$ & Mean & $\begin{array}{l}\text { Standard } \\
\text { deviation }\end{array}$ \\
\hline \multirow{6}{*}{$\begin{array}{l}\text { Hexavalent } \\
\text { Chromium }\end{array}$} & 0 & 90 & 90 & 90 & 90 & 0 \\
\hline & 2 & 69 & 68 & 68 & 68 & 0.57735 \\
\hline & 4 & 54 & 53 & 53 & 53 & 0.57735 \\
\hline & 6 & 35 & 32 & 32 & 33 & 1.732051 \\
\hline & 8 & 20 & 15 & 15 & 16 & 2.886751 \\
\hline & 10 & 0 & 0 & 0 & 0 & 0 \\
\hline
\end{tabular}

\section{Molecular identification of metal-reducing microorganism:}

A significant advantage of this protocol is that a microorganism isolate is known at intervals 2 or 3 days than typical biochemical tests, which usually takes many weeks. Various previous reports recommended that 16S rRNA sequence analysis is superior compared to standard makeup ways in distinguishing microorganisms [20-23]. The PCR amplified product of $1500 \mathrm{bp}$ of the polymer section shows the $16 \mathrm{~S}$ rRNA sequence amplification within the image made by the gel documentation system Fig. 3. Similar methods used to determine metal resistance microorganisms from soil samples in the electroplating business [24, 25]. Gupta et al. (2018) declared that metal enzyme microorganism enterobacteria sp. was known by the 16S rRNA sequence and also the same technique wont 
to determine the Cellulosimicrobium sp. isolated from workplace waste matter. During this study, the microorganism was known as Bacillus subtilis (Accession No: MT554031.1) by 16S rRNA sequencing. The isolated microorganism showed a 100 percent similarity with reference sequence retrieved from NCBI (Fig 2, 3).

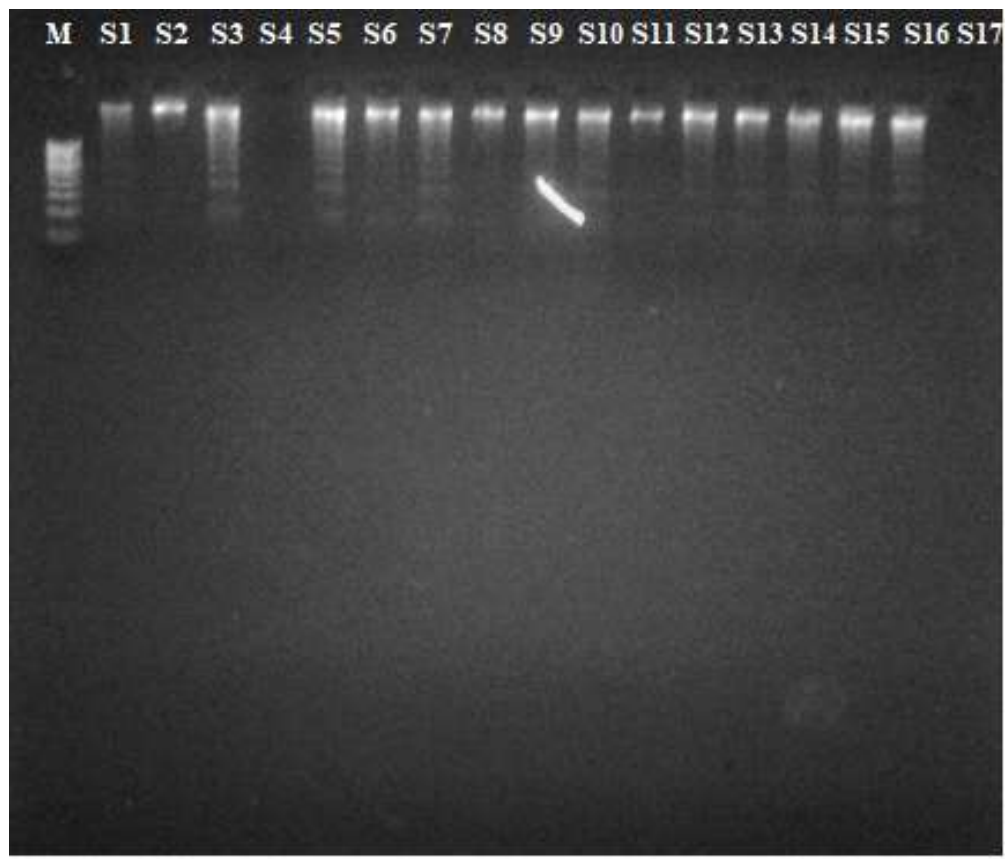

Fig 2:- DNA isolation from bacterial species.

\section{PCR amplification of samples:}

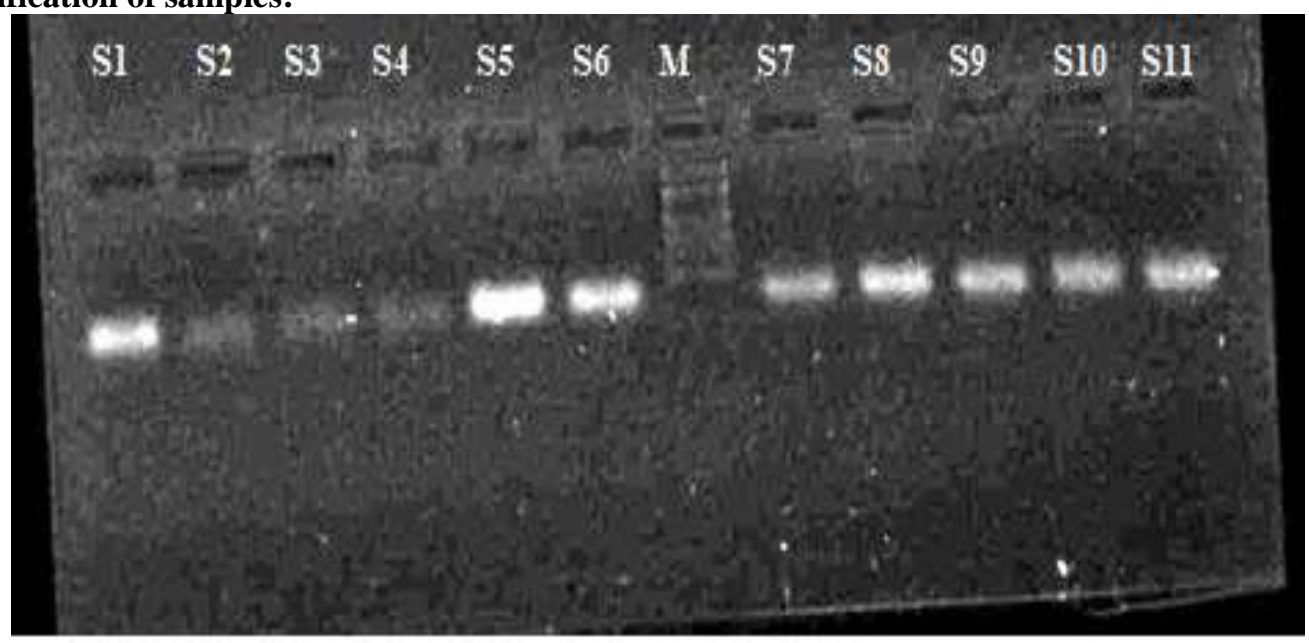

Fig 3:- PCR amplification of isolated microorganism species.

\section{Phylogenetic analysis:}

The tree of the microorganism Bacillus strain ANUES03 reveals that this specific microorganism strain has been originated directly from associate degree unknown common antecedent. This unknown common antecedent has additionally given rise to 5 connected strains from several intermediate strains through many genomic variations on varied generations [26-30]. None of those connected strains show serious metal tolerance; which can ensure the genomic variations that had occurred on varied generations. The isolate Bacillus subtilis strain ANUES03, that is that the direct relative of the unknown common antecedent should have preserved its novel characteristic of serious metal tolerance. Additionally a break for different serious metal tolerant Bacillus strains originating from an identical unknown common ancestor as shown in the tree (Fig. 4). 


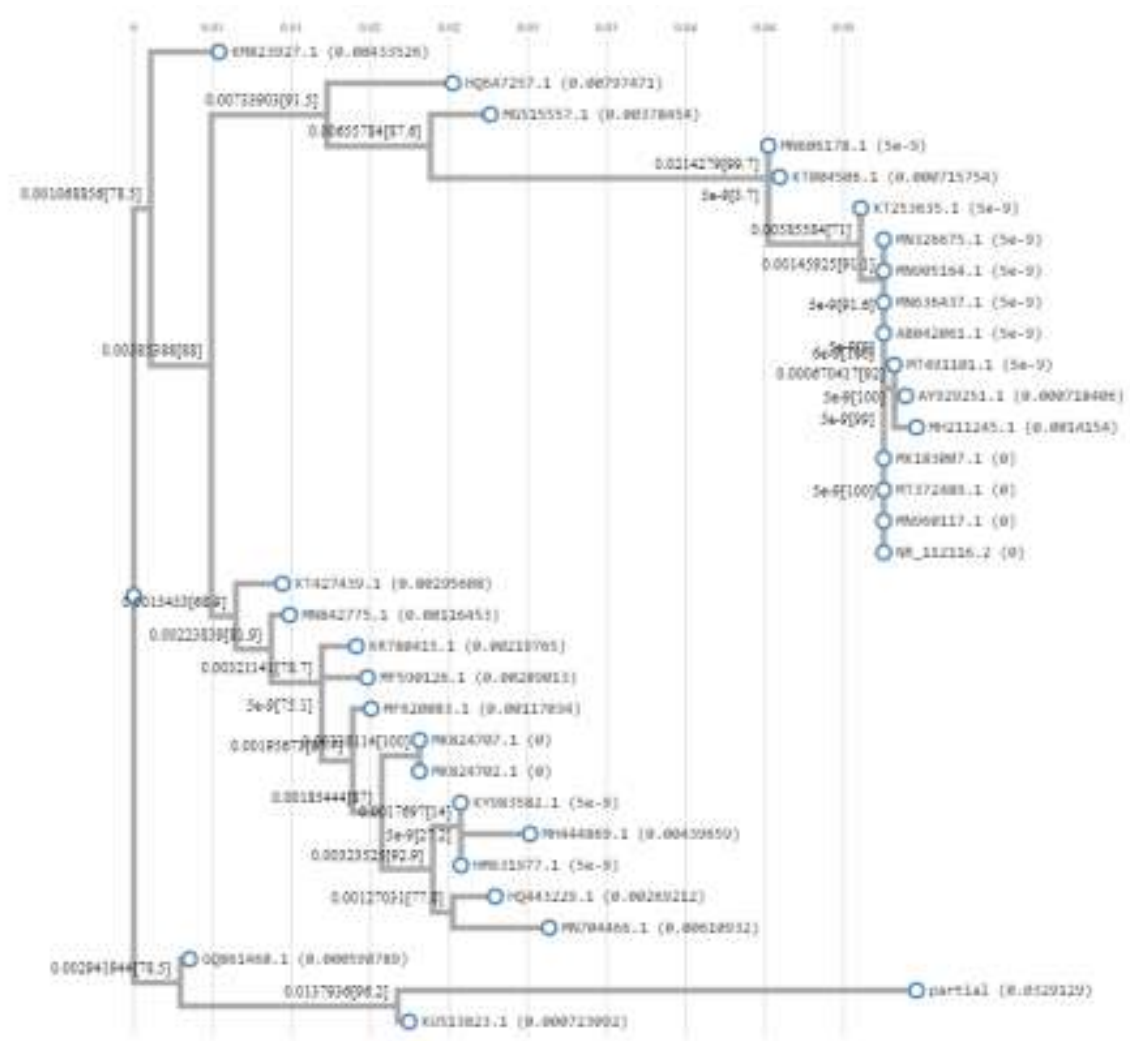

Fig 4:- Phylogenetic analysis of Bacillus subtilis strain ANUES03.

\section{Conclusion:-}

It is concluded from this study that indigenous microorganism species from impure samples and effluents use their innate ability to degrade pollutants like chromium that is additionally economically viable compared to standard ways. Microorganism species Bacillus subtilis strain ANUES03 was isolated and known through molecular techniques. They have a high reducing ability for chromium (VI) up to $80 \mathrm{mg} / 1$ and $100 \mathrm{mg} / \mathrm{l}$ chromium severally. As these species have vital potential to scale back the toxicant hexavalent chromium, this property is controlled to detoxify the metal-contaminated sites. Therefore, these findings are extremely relevant to the industries from the angle of bioremediation as this could even be practiced within the metal recovery techniques within the mining industries. However, any improvement studies are needed to optimize the characters of these microorganisms before they can be used to reduce the concentration of metal.

\section{References:-}

1. M.A. Ainsworth, C.P. Tompsett, A.C. DeanCobalt and Nickel sensitivity and tolerence in Klebsiellapneumonia Microbios, 27 (109-110) (1980), pp. 175-184

2. R.N. Bharagava, S. MishraHexavalent chromium reduction potential of Cellulosimicrobium sp. isolated from common effluent treatment plant of tannery industriesEcotox. Environ. Saf., 147 (2018), pp. 102-109

3. P.P. Bosshard, S. Abels, R. Zbinden, E.C. Böttger, M. AltweggRibosomal DNA Sequencing for identification of aerobic gram-positive rods in the clinical laboratory (an 18-Month Evaluation)J. Clin. Microbiol., 41 (9) (2003), pp. 4134-4140

4. P. Deng, X. Tan, Y. Wu, Q. Bai, Y. Jia, H. XiaoCloning and sequence analysis demonstrate the chromate reduction ability of a novel chromate reductase gene from SerratiaspExp. Ther. Med., 9 (3) (2015), pp. 795-800

5. K. Deshpande, S. Cheung, M.S. Rao, B.C. DaveEfficient sequestration and reduction of hexavalent chromium with organosilica sol-gelsJ. Mater. Chem., 15 (2005), pp. 2997-3004

6. S. Farag, S. ZakiIdentification of bacterial strains from tannery effluent and reduction of hexavalent chromiumJ. Environ. Biol., 31 (5) (2010), pp. 877-88

7. Flores, J.M. PerezCytotoxicity, apoptosis, and in vitro DNA damage induced by potassium chromateToxicol. Appl. Pharmacol., 161 (1) (1999), pp. 75-81 
8. P. Gupta, K. Vipin, Z. Usmani, R. Rani, R. ChandraPhosphate solubilization and chromium (VI) remediation potential of Klebsiella sp. strain CPSB4 isolated from the chromium contaminated agricultural soilChemosphere, 192 (2018), pp. 318-327

9. M. Ilias, I.F. Rafiqullah, B.C. Debnath, K.S.B. Mannan, M.M. HoqIsolation and characterization of chromium(VI)-reducing bacteria from tannery effluentsIndian J. Microbiol., 51 (1) (2011), pp. 76-81

10. T.C. Joseph, A.M. Varghese, A. Baby, D. Reghunathan, V. Murugadas, K.V. LalithaFirst draft genome sequence of a member of the genus Mangrovibacter, isolated from an aquaculture farm in IndiaGenome Announcements, 2 (6) (2014), pp. e01209-e1214

11. J. Kotas, Z. StasickaChromium occurrence in the environment and methods of its speciationEnviron. Pollut., 107 (3) (2000), pp. 263-283

12. S. Kumar, G. Stecher, K. TamuraMEGA7: molecular evolutionary genetics analysis version 7.0 for bigger datasetsMol. Biol. Evol., 33 (7) (2016), pp. 1870-1874

13. T.L. Marsh, M.J. McInerneyRelationship of hydrogen bioavailability to chromate reduction in aquifer sedimentsAppl. Environment. Microbiol., 67 (4) (2001), pp. 1517-1521

14. S.P. McGrath, S. SmithChromium and nickelB.J. Alloway (Ed.), Heavy Metals in Soils, Willy, New York (1990), pp. 125-150

15. O.J. Nriagu, E. NieboerChromium in the Natural and Human EnvironmentJohn Wiley and sons, New York (1988), pp. 1-591

16. R.C. Patra, S. Malik, M. Beer, M. Megharaj, R. NaiduMolecular characterization of chromium (VI) reducing potential in gram positive bacteria isolated from contaminated sitesSoil Biol. Biochem., 42 (10) (2010), pp. 1857-1863

17. D. Pradhan, L.B. Sukla, M. Sawyer, P.K.S.M. RahmanRecent bioreduction of hexavalent chromium in wastewater treatment: a reviewJ. Ind. Eng. Chem. (2017), 10.1016/j.jiec.2017.06.040

18. D.V. Ribeiro, S.Y. Yuan, M.R. MorelliEffect of chemically treated leather shavings addition on characteristic and microstructure of OPC mortarsMat. Res., 15 (1) (2012), pp. 136-143

19. P. Saranraj, P. Sivasakthivelan, S.S. SakthiPrevalence and production of plant growth promoting substance by Pseudomonas fluorescens isolates from paddy rhizosphere soil of cuddalore district, Tamil Nadu, IndiaAfr. J. Basic Appl. Sci., 5 (2) (2013), pp. 95-101

20. R. Shah, J. Patel, B.D. Prasad, P. KumarThe P-type ATPase mediates copper tolerance in Klebsiella pneumoniae IFCu4 strain isolated from south Gujarat industrial effluentsJ. Pharmacy Appl. Sci., 1 (1) (2014), pp. 1-7

21. O.P. Shukla, U.N. Rai, N.K. Singh, S. Dubey, V.S. Baghellsolation and characterization of chromate resistant bacteria from tannery effluentJ. Environ. Biol., 28 (2) (2007), pp. 399-403

22. W.A. Smith, W.A. Apel, J.N. Petersen, B.M. PeytonEffect of carbon and energy source on bacterial chromate reductionBioremed. J., 6 (3) (2002), pp. 205-215

23. Y.W. Tang, A.V. Graevenitz, M.G. Waddington, M.K. Hopkins, D.H. Smith, H. Li, C.P. Kolbert, S.O. Montgomery, D.H. PersingIdentification of coryneform bacterial isolates by ribosomal DNA sequence analysisJ. Clin. Microbiol., 38 (4) (2000), pp. 1676-1678

24. S. Viamajala, B.M. Peyton, R.K. Sani, W.A. Apel, J.N. PetersenToxic effects of chromium (VI) on anaerobic and aerobic growth of Shewanellaoneidensis MR-1Biotechnol. Prog., 20 (1) (2004), pp. 87-95

25. G. Wang, B. Zhang, S. Li, M. Yang, C. YinSimultaneous microbial reduction of vanadium (V) and chromium (VI) by Shewanellaloihica PV-4Biores. Technol., 227 (2017), pp. 353-358

26. P.A. Wani, A.B. Omozele, I.A. Wasiu, K.O. JamiuCr (VI) Reduction by indigenous Bacillus species PB5 isolated from contaminated soil of abeokutaogun state, NigeriaInt. J. Soil Sci., 10 (4) (2015), pp. 203-210

27. P.A. Wani, S. Wahid, R. Singh, A.M. KehindeAntioxidant and chromium reductase assisted chromium (VI) reduction and $\mathrm{Cr}$ (III) immobilization by the Rhizospheric Bacillus helps in the remediation of $\mathrm{Cr}$ (VI) and growth promotion of soybean cropRhizosphere (2018), 10.1016/j.rhisph.2018.01.004

28. W. Xiao, X. Ye, X. Yang, Z. Zhu, C. Sun, Q. Zhang, P. XuIsolation and characterization of chromium (VI)reducing Bacillus sp. FY1 and Arthrobacter sp. WZ2 and their bioremediation potentialBioremediat. J. (2017), 10.1080/10889868.2017.1282939

29. Sumit Yadav, O.P. Shukla, U.N. RaiChromium Pollution and BioremediationNational Botanical Research Institute, Lucknow (2005). 